\title{
DARI GENERASI MILENIAL HINGGA GENERASI ALFA: ANALISIS NAMA MASYARAKAT BANARAN-BUGEL
}

\section{FROM MILLENIAL TO ALPHA GENERATIONS: NAMING OF BANARAN-BUGEL COMMUNITY}

\author{
Ferdian Achsani
}

SMPN 1 Weru, Sukoharjo

Ponsel: 085728796969; Pos-el: dwikurniawan219@gmail.com

\begin{abstract}
Abstrak
Penelitian ini merupakan penelitian deskriptif kualitatif yang bertujuan untuk mendeskripsikan penamaan masyarakat di dukuh Banaran-Bugel. Pengumpulan data dilakukan dengan cara observasi dan wawancara, yaitu peneliti terjun langsung ke masyarakat dan melakukan wawancara terhadap nama-nama pada generasi milenial hingga generasi alfa di dukuh tersebut. Analisis data menggunakan model interaktif yang meliputi proses pengumpulan data, penyajian data dan penarikan kesimpulan. Hasil penelitian menunjukkan bahwa penamaan masyarakat di dukuh Banaran-Bugel mengalami perkembangan dari yang semula tradisional beralih ke nama-nama modern. Hal ini dapat dilihat dari beberapa nama-nama generasi milenial hingga generasi alfa yang diambil dari beberapa bahasa seperti bahasa Arab, Sansekerta, Jawa, dll. Meskipun demikian, Proses penamaan di dukuh ini dapat dilihat dari beberapa klasifikasi seperti urutan kelahiran, bulan kelahiran, penanda jenis kelamin, harapan sifat yang meliputi sifat benda dan sufat manusia, harapan, dan gabungan nama orang tua.
\end{abstract}

Kata kunci: penamaan; milenial; alfa

\section{Abstract}

This research is a descriptive qualitative research which aims to describe the naming of the community in the hamaran of Banaran-Bugel. Data collection was carried out by means of observation and interviews, ie researchers went directly to the community and conducted interviews on the names of the millennial generation to the alpha generation in the hamlet. Data analysis uses an interactive model which includes the process of collecting data, presenting data and drawing conclusions. The results showed that the naming of the community in the Banaran-Bugel hamlet experienced a development from what was traditionally shifted to modern names. This can be seen from several millennial names to alpha generation taken from several languages such as Arabic, Sanskrit, Javanese, etc. Even so, the naming process in this hamlet can be seen from several classifications such as birth order, birth month, sex markers, expectancy traits that include the nature of human objects and sufat, expectations, and the combined names of parents.

Keywords: naming; millenial; alpha 


\section{PENDAHULUAN}

Setiap bayi atau anak yang terlahir di dunia pasti akan diberikan nama oleh orang tuanya. Hal ini sudah menjadi kewajiban yang mutlak, sebab nama akan menjadi penanda atau identitas pembeda anak tersebut dengan orang lain. Bahkan sebelum anak terlahir di dunia, orang tua sudah menyiapkan calon nama yang dipilihkannya kepada anaknya. Dalam ajaran agama Islam, memberikan nama bagi bayi dapat dilakukan ketika hari ketujuh, bersamaan dengan akikah dan potong rambut. Hal ini semakin memperjelas bahwa nama sangat penting bagi manusia.

Selain karena nama yang menjadi perhiasan bagi manusia, tentu nama juga menyimpan harapan dan doa dari orang yang memberikannya. Nama pada diri seseorang akan melambangkan sifat, kepribadian ataupun karakter orang tersebut. Ascalonicawati menyatakan bahwa, nama bukan hanya sekadar sapaan belaka, tetapi nama juga sebagai harapan dari orang tua. Maka, sebagai orang tua sudah tentu harus memberikan nama yang tidak hanya indah di luar, tetapi juga baik di dalam yang memiliki makna sebagai harapan atau cerminan sang anak. Resticka \& Sri (2018), menambahkan bahwa nama yang diberikan oleh orang tua umumnya sesuai dengan perkembangan zaman, kebanggaan memberikan nama yang anggun dan memiliki daya saing serta kebanggaan memberikan nama-nama yang bermartabat.

Pemberian nama dari orang tua kepada anak biasanya dilatarbelakangi oleh faktor budaya ataupun konteks sosial yang terjadi di masyakat. Misalnya, waktu kelahiran, urutan kelahiran ataupun sebagai penanda jenis kelamin (Dewi, Roni, \& Paulina, 2012). Masyarakat Bali misalnya, dalam memberikan nama, ratarata memiliki kesamaan yang dapat dilihat dari penggunaan kata sandang, sifat dan bilangan. Hal ini dapat kita jumpai bahwa rata-rata masyarakat Bali sering menggunakan kata I-, Ni-, Bagus, Ayu, sebagai pembeda antara jenis kelamin lakilaki dengan perempuan (Bandana, 2015). Selain masyarat Bali, penamaan pada masyarakat Melayu juga dapat dijadikan sebagai bukti bahwa faktor budaya turut melatarbelakangi proses penamaan diri anak (Aditya, Saman, \& Syam, 2016).

Selain faktor budaya masyarakat atau geografis, pemberian nama anak juga ditemui melalui fenomena sosial yang terjadi di masyakat. Salah satu nama yang unik ini ditemui dari keluarga Asep Sutiyo yang memberikan nama ketiga putraputrinya dengan nama Republik, Indonesia dan Merdeka. Diwawancarai oleh Dedy 
Corbuzier (2019) dalam acara Hitam

Putih, Sutiyo mengaku bahwa pemberian nama tersebut dilatarbelakangi oleh keprihatinannya terhadap kericuhan yang terjadi di Indonesia pada tahun 1998. Untuk mengingatnya, Sutiyo menamai ketiga putra-putrinya dengan nama Republik, Indonesia, dan Merdeka. Selain itu, pemberiaan nama Alhamdulillah Lanang Anakku (disapa Elak) juga dapat dijadikan contoh bahwa pemberian nama pada orang juga dapat dilatarbelakangi oleh harapan atau bentuk wujud syukur. Terkabulnya harapan kedua orang tua Elak yang berharap memiliki anak laki-laki pun akhirnya menjadi faktor latar belakang pemberian nama tersebut.

Pemberian nama pada masyarakat Jawa menjadi salah satu hal yang unik untuk dikaji. Keunikan orang tua dalam memberikan nama pada anaknya dapat dilihat dari karakteristik, seperti weton, neptu, pasaran, peristiwa penting yang sudah melekat di masyarakat Jawa. Seperti, nama Paijo yang artinya anak yang lahir di hari selasa. Sutiman, yang artinya anak yang lahir pada pasaran neptu pahing. Bahkan, nama gabungan antara hari dan pasaran seperti Tugino yang artinya anak yang lahir di hari sabtu legi. Adapula pemberian nama diri seperti Hariyadi yang merupakan akronim dari hari raya Idul Fitri. Pemberian nama ini didasarkan karena orang tersebut lahir pada hari raya umat islam. Selain itu, ada pula nama Slamet yang berisi harapan orang tua kepada anak agar dapat selamat fidunnya wal akhirat

Namun, seiring perkembangan teknologi yang melahirkan generasi milenial, $\mathrm{Z}$ dan alpha menuntut namanama yang semula dianggap tradisional menjadi modern. Pemberian nama masyarakat Jawa sudah tidak lagi memperhatikan karakteristik-karakteristik seperti pada masyarakat Jawa zaman dahulu. Pemberian nama tersebut sudah tidak lagi digunakan oleh orang tua dalam memberikan nama pada anaknya. Sebab, dianggap kuno dan ketinggalan zaman. Orang tua memilihkan nama-nama modern yang dianggap lebih gaul dan mengikuti arus tren perkembangan zaman.

Selain itu, perubahan nama tradisional ke modern juga dilatar belakangi oleh generasi kelahirannya seperti generasi milenial, generasi $z$, maupun generasi alfa. Generasi milenial merupakan generasi yang lahir di awal kemunculan teknologi informasi yang mulai berkembang. Generasi ini lahir pada awal tahun 1980-an hingga tahun 1995. Setelah berakhirnya generasi $\mathrm{Y}$ atau generasi milenial, lahir kembali generasi Z. Generasi ini lahir dan berkembang di era teknologi digital yang semakin maju 
dan semakin pesat. Teknologi ini akhirnya menjadikan generasi $\mathrm{Z}$ sebagai pecandu teknologi seperti jejaring sosial YouTube, Netflix, Instagram, belanja online, dll. Generasi Z lahir umumnya lahir pada tahun 1995--2010. Berakhirnya generasi Z, melahirkan generasi alfa. Generasi ini lahir di tengah perkembangan teknologi globalisasi yang semakin maju. Adanya perkembangan teknologi informasi ini menjadikan generasi alfa sebagai generasi yang sangat bergantung pada teknologi. Mereka bagaikan tidak bisa hidup tanpa teknologi dan menjadi ketergantungan dengan teknologi.

Begitu pun fenomena pemberian nama yang terjadi di masyarakat Dukuh Banaran-Bugel, Desa Tegalsari, Kabupaten Sukoharjo, Jawa Tengah mengalami perubahan yang unik. Dapat dikatakan unik sebab orang tua pada zaman dahulu memberikan nama kepada anaknya yang masih sederhana. Tetapi, seiring perkembangan zaman, masyarakat di desa ini sudah tidak lagi menggunakan nama-nama tersebut dan beralih pada pemberian nama yang lebih modern seperti Keisa, Briyan, Rifki, Isna, Andre, Aji, Cinta, Iqbal, dll. Orang tua memilihkan nama-nama modern yang dianggap lebih keren dan mengikuti arus tren perkembangan zaman.
Penelitian terkait penamaan nama orang pernah dilakukan oleh (Temaja, 2017). Dalam penelitian yang berjudul Sistem Penamaan Orang Bali menyimpulkan bahwa sistem penamaan masyarakat Bali dibagi menjadi tiga yaitu penamaan sebagai penanda jenis kelamin, urutan kelahiran dan berdasarkan empat sistem kasta. Proses penamaan tersebut masih berjalan dan berlaku hingga saat ini, meskipun hampir ada beberapa yang mulai meninggalkan sistem ini karena adanya proses globalisasi. Persamaan penelitian ini dengan penelitian tersebut adalah mengkaji proses penamaan pada masyarakat. Perbedaannya terdapat pada objek yang dikaji antara masyarakat Bali dengan masyarakat Jawa.

Penelitian lain yang relevan dengan penelitian ini, pernah dilakukan oleh Khotimah \& Ika (2019) yang dimuat dalam Jurnal Pendidikan Bahasa dan Sastra Indonesia. Dalam penelitian yang berjudul Kajian Semantik Nama Diri Mahasiswa Madura di Prodi Pendidikan Bahasa dan Sastra Indonesia Universitas Trunojoyo Madura tersebut, disimpulkan bahwa dalam proses pemberian penamaan mahasiswa Madura terdapat akulturasi antara kebudayaan Jawa dan Arab. Hal ini dapat dilihat dari nama diri mahasiswa yang notabenenya merupakan gabungan antara bahasa Jawa dengan bahasa Arab. 
Persamaan dengan penelitian tersebut adalah mengkaji penamaan pada suatu komunitas. Perbedaannya terletak pada objek yang dikaji antara nama diri mahasiswa Madura Prodi Pendidikan Bahasa dan Sastra Indonesia Universitas Trunojoyo Madura dengan nama diri anakanak generasi millennial hingga generasi alfa di Dukuh Banaran-Bugel, Desa Tegalsari, Kabupaten Sukoharjo.

\section{Landasan Teori}

Melalui proses penamaan, pemberi nama telah memberikan tanda terhadap suatu objek untuk mudah dikenali. Bukan hanya sekadar pemberian nama agar lebih dikenal oleh orang lain, tetapi dalam proses penamaan juga mengandung makna-makna tertentu. Dalam setiap objek yang sama tentu memiliki penamaan yang berbeda. Adanya perbedaan makna tersebutlah yang membedakan dengan objek lain yang memiliki kesamaan bentuk.

Dalam proses penamaan terhadap nama orang bertujuan untuk memudahkan mengenali identitas jati diri seseorang. Aditya dkk (2016) menyatakan bahwa pemberian nama anak dari orang tua berisi tentang pengetahuan orang tua mengenai nama anak, harapan atau cita-cita orang tua pada anak, budaya dominan yang memengaruhi dalam pemberian nama, stratifikasi sosial, urutan kelahiran anak dalam keluarga, agama yang dianut serta ada tidaknya pengaruh bahasa asing dalam pemberian nama. Pemberiaan nama orang ini bertujuan untuk mengenal dan memberikan identitas terhadap seseorang dalam proses pendataan dan identifikasi. Ketika, orang tua memberikan nama terhadap anaknya, pasti dilatarbelakangi oleh faktor psikologis dan sosiologi. Faktor psikologis berpengaruh berdasarkan keadaan psikolog orang yang memberikan nama. Misalnya, dalam keadaan bahagia, orang tua memberikan nama Alhamdulillah sebagai bentuk rasa syukurnya. Pengaruh sosiologi terhadap pemberian nama anak berpengaruh pada keadaan sosial budaya masyarakat. Misalnya, ketika pendidikan orang tua pernah belajar di pesantren atau orang tua dipandang sebagai seorang ulama, tentu dalam memberikan anaknya juga bernuansa islami, seperti nama Muhammad, Syaifullah, dll. Di samping faktor psikologi dan sosiologi, Fatikhudin (2018) mengatakan bahwa penamaan perlu dilakukan demi untuk mengetahui motivasi pembentukan nama. Di era modern saat ini, pemberian nama anak dapat dilihat melalui beberapa hal. Misalnya, waktu kelahiran, urutan kelahiran, hari besar keagamaan, mengidolakan tokoh, tempat kelahiran, 
peristiwa tertentu, akronim dan kesamaan nama depan (Dewi dkk 2012). Hal ini juga sesuai dengan yang disampaikan oleh (Rohardiyanto, 2019) bahwa pembentukkan nama diri dapat dilihat melalui harapan orang tua, adopsi tokoh dan orang tua, terpengaruh karena suatu peristiwa serta tempat dan waktu.

\section{Metode Penelitian}

Penelitian ini termasuk dalam jenis deskriptif kualitatif. Deskriptif kualitatif merupakan salah satu jenis penelitian yang menjabarkan atau mendeskripsikan hasil akhirnya berdasarkan fakta dan fenomena yang ditemui dalam bentuk deskripsi bukan dalam hitungan statistik. Tetapi, juga tidak dapat dipungkiri bahwa penelitian deskriptif kualitatif juga menggunakan hitungan statistik untuk menghitung jumlah temuan data yang dihimpun oleh peneliti. Objek penelitian ini yaitu nama-nama diri masyarakat generasi milenial hingga generasi alfa yang terdapat di Dukuh Banaran-Bugel, Kadus IV Desa Tegalsari, Kecamatan Weru, Kabupaten Sukoharjo, Provinsi Jawa Tengah. Pemilihan penamaan masyarakat dari generasi milenial hingga generasi alfa dilatarbelakangi karena ingin menjabarkan bentuk nama-nama modern di Kadus IV Desa Tegalsari. Proses pengumpulan data dilakukan melalui teknik wawancara dan observasi. Peneliti melakukan wawancara tak bersturktur yaitu dengan memberikan pertanyaan secara garis besar permasalahan terhadap beberapa orang tua (responden) (Sugiyono, 2012). Teknik observasi dilakukan melalui pengamatan data dengan mencari arti dari masing-masing nama yang terdapat di media massa. Teknik analisis data dilakukan melalui pengumpulan data, pemilihan data, dan penarikan simpulan. Setelah peneliti mengumpulkan namanama yang menjadi objek penelitian, peneliti melakukan pemilihan terhadap nama-nama tersebut, kemudian dikategorikan sesuai dengan kategori masing-masing nama.

\section{Pembahasan}

\subsection{Urutan Lahir}

\begin{tabular}{c}
\hline Nama \\
\hline Wakhid Anshori \\
\hline Isnaini Dwi Saputro \\
\hline Tri Hastanto \\
\hline Dwi Nur Rahman
\end{tabular}

Beberapa contoh nama di atas merupakan bentuk nama-nama sesuai dengan urutan lahir yang berada di Kadus IV Desa Tegalsari. Urutan nama-nama di atas dapat dilihat penggunaannya, baik dari bahasa Arab maupun bahasa Jawa. Penggunaan bahasa Arab dapat dilihat dari nama Wakhid Anshori dan Isnaini Dwi Saputro. Dalam bahasa Arab, kata Wakhid 
berarti satu, sedangkan kata Isnaini memiliki arti dua. Dengan demikian, penggunaan nama Wakhid dan Isnaini sebagai nama diri ini memiliki makna sebagai anak pertama dan kedua dalam keluarga. Perlu diketahui bahwa pemilihan nama bagi Kedua orang ini tidak dalam satu keluarga atau dikatakan sebagai saudara.

Selain penggunaan nama yang diambilkan dari bahasa Arab sebagai urutan lahir, penggunaan bahasa Jawa sebagai nama anak juga diketemukan di Kadus IV Desa Tegalsari. Hal ini dapat dilihat dari nama Tri Hastanto dan Dwi Nur Rahman. Dalam bahasa Jawa, kata tri memiliki arti tiga, sedangkan kata dwi memiliki arti dua. Dengan demikian, dapat diketahui bahwa penggunaan kata tri dan dwi sebagai nama diri ini didasari karena si anak lahir urutan kedua dan ketiga dalam keluarga. Sama dengan sebelumnya, nama tri dan dwi ini tidak dalam kondisi satu keluarga. Banyak sekali ditemukan beberapa nama yang menggunakan kata tri dan dwi di Kadus IV Desa Tegalsari ini. Pemilihan nama tri dan dwi sebagai nama diri ini didasari karena motif nama-nama tersebut dirasa sudah bagus dan mengikuti pola perkembangan zaman.

Dari uraian tersebut, dapat dilihat bahwa adanya penggunaan bahasa asing maupun bahasa daerah dalam penamaan masyarakat Kadus IV Desa Tegalsari. Penggunaan bahasa asing terlihat dengan adanya penggunaan bahasa Arab, sedangkan penggunaan bahasa daerah menggunakan bahasa Jawa sesuai bahasa kesehariannya.

\subsection{Terinspirasi Tokoh}

\begin{tabular}{c}
\hline Nama \\
\hline Titus Hermawan \\
\hline Yusuf Iskandar \\
\hline Ilyas Nasrullah \\
\hline Arjuna Sastra Gumilang \\
\hline
\end{tabular}

\section{Titus Hermawan}

Nama Titus Hermawan ditemukan di salah sahabat Rasul Paulus dalam sidang Kristen pada abad pertama. Titus merupakan salah satu tokoh Nasrani yang sangat berjasa menjaga kebersihan sidang Kristen pada abad pertama. Atas keberaniannya tersebut, ia diartikan sebagai seorang yang terhormat. Nama Hermawan sendiri dari bahasa Indonesia memiliki arti pemberani. Dengan demikian, nama Titus Hermawan dapat diartikan sebagai laki-laki yang pemberani dan terhormat.

2. Yusuf Iskandar

Pengambilan Nama Yusuf Iskandar bagi nama diri dapat dikatakan terinspirasi dari seorang nabi yang terkenal akan ketampanannya. Kata Yusuf merujuk pada salah satu tokoh Nabi Yusuf yang diyakini memiliki ketampanan yang luar biasa. Dari 
cerita tersebut, penamaan Yusuf pada nama diri ini dapat dikatakan bahwa orang tua berharap anaknya juga memiliki ketampanan yang serupa dengan Nabi Yusuf. Sedangkan, nama Iskandar juga diambil dari Bahasa Arab yang memiliki arti pembela agama Islam. Dalam Bahasa Yunani, nama Iskandar memiliki arti sebagai laki-laki yang mampu bertahan.

Dengan demikian, pemberian nama Yusuf Iskandar dapat diartikan sebagai laki-laki tampan yang mampu bertahan sebagai pembela agama Islam.

3. Ilyas Nasrullah

Pemberian Nama Ilyas juga dapat dikatakan karena terinspirasi dari tokoh Nabi Ilyas yang tak lelah berjuang untuk berdakwah dan menyebarluaskan ajaran agama Islam kepada umatnya. Perjalanan Nabi Ilyas menyebarkan agama Islam tersebut tidaklah mudah. Ia harus mengalami banyak tekanan dari umatnya yang menyembah berhala. Akan tetapi, Nabi Ilyas tidak pernah lelah untuk terus mensyiarkan agama Islam kepada umatnya. Hal tersebut, mendasari penamaan Ilyas pada nama diri ini. Pemberian nama Ilyas diharapkan agar anak dapat memiliki semangat pantang menyerah dan terus berjuang dalam segala hal dan rintangan, terutama dalam berdakwah dan menegakkan agama.
Pemberian nama Ilyas yang dilengkapi dengan kata Nasrullah ini semakin memiliki makna yang kuat. Kata Nasrullah yang dalam Bahasa Arab memiliki arti Pertolongan Allah yang diberikan untuk seorang anak laki-laki, nama Ilyas Nasrullah memiliki makna bahwa setiap usaha dan kerja keras yang dilakukannya akan selalu mendapat pertolongan dari Allah.

\section{Arjuna Sastra Gumilang}

Mendengar kata Arjuna, tentu sudah tidak asing lagi bagi telinga masyarakat Indonesia. Ia merupakan salah satu tokoh Pandawa Lima yang terkenal bukan hanya karena ketampanannya, tetapi juga sifat cerdik dan pandai, pendiam, bijaksana, sopan-santun, berani dan suka melindungi yang lemah.

Dengan demikian, pemberian nama Arjuna pada nama anak diharapkan agar anaknya memiliki ketampanan dan perwujudan laki-laki yang sempurna, juga berisi harapan agar sang anak memiliki sifat dan karakter yang sama dengan sang tokoh.

Selanjutnya, pada kata sastra diambil dari kata sastro yang artinya ilmu pengetahuan. Sedangkan, pada kata Gumilang, diambil dari kata gemilang yang mana dalam bahasa Indonesia memiliki arti `bersinar’. 
Dengan demikian, dapat disimpulkan bahwa pemberian nama Arjuna Sastra Gumilang memiliki harapan agar anak lelakinya tersebut dapat menjadi laki-laki yang paling tampan dan bersinar serta memiliki ilmu pengetahuan yang luas.

\subsection{Penanda Jenis Kelamin}

\begin{tabular}{l|l}
\hline Nama & Jenis Kelamin \\
\hline $\begin{array}{l}\text { Cundhoko Joko Nur } \\
\text { Mursyid }\end{array}$ & Laki-Laki \\
\hline Bagus Darmawan & Laki-Laki \\
\hline Pria Maulana Sejati & Laki-Laki \\
\hline Putri Nur Nirmalasari & Perempuan \\
\hline Ayu & Perempuan \\
\hline Annisa Wijayanti & Perempuan \\
\hline
\end{tabular}

1. Cundhoko Joko Nur Mursyid

Kata Joko dalam Bahasa Jawa memiliki makna perjaka atau laki-laki yang balig yang siap untuk menikah. Banyak sekali ditemukan beberapa nama Joko yang berada di masyarakat Kadus IV Desa Tegalsari. Pemberian nama Joko sebagai nama diri anak ini dapat dikatakan sebagai identitas bahwa sang anak adalah seorang yang berjenis kelamin laki-laki.

Tetapi, jika dilihat secara keseluruhan, nama Cundhoko Joko Nurmursyid ini memiliki makna sebagai laki-laki yang taat dalam beribadah, baik hati, dan sopan sebagai cahaya petunjuk. Hal ini, dapat dilihat dari arti kata Cundhoko yang memiliki makna beribadah, baik dan sopan, nur dalam bahasa Arab memiliki arti cahaya dan mursyid dalam bahasa Irysada memiliki makna petunjuk.

\section{Bagus Darmawan}

Kata Bagus dalam bahasa Jawa sering diartikan sebagai seorang laki-laki yang memiliki wajah yang tampan dan menawan. Dalam bahasa Indonesia, kata bagus dimaknai sebagai bagus sekali atau sangat elok. Pemberian nama bagus pada penamaan anak ini dapat dijadikan sebagai penanda jenis kelamin laki-laki. Pemberian nama Bagus tersebut memiliki harapan agar sang anak memiliki wajah yang tampan rupawan. Sedangkan, kata Darmawan dapat diartikan sebagai orang yang jujur atau amanah. Sehingga dapat disimpulkan bahwa pemberian nama Bagus Darmawan ini menandakan sebagai laki-laki yang jujur dalam setiap tutur kata atau juga dapat dikatakan sebagai laki-laki yang amanah dan dapat dipercaya.

\section{Pria Maulana Sejati}

Mendengar nama Pria Maulana Sejati, tentu sudah terbesit di pikiran bahwa pemilik nama tersebut berjenis kelamin laki-laki. Hal ini dapat dilihat dari kata pria yang dalam bahasa Indonesia memiliki makna laki-laki dewasa. Dengan demikian, pemberian nama diri pria ini dapat dikatakan sebagai penanda bahwa orang tersebut berjenis kelamin laki-laki. 
Dilihat secara keseluruhan nama tersebut memiliki arti yang bagus. Kata Pria yang berarti laki-laki, kata Maulana yang berarti pelindung dan kata Sejati berarti sesungguhnya jika digabungkan memiliki arti laki-laki pelindung yang sesungguhnya. Maksud dari penamaan tersebut adalah bahwa orang tua menaruh harapan agar sang anak menjadi laki-laki pelindung bagi siapapun.

4. Putri Nur Nirmalasari, Deva Ayu Pitaloka dan Annisa Wijayanti

Kata Putri, Ayu dan Annisa dalam pemberian nama anak di atas memiliki makna sebagai penanda perempuan. Hal ini dapat dilihat bahwa nama Putri dalam KBBI memiliki makna sebagai anak perempuan, kata ayu yang dalam Bahasa Indonesia memiliki makna cantik atau anggun, dan kata annisa dalam bahasa Arab memiliki arti perempuan.

Dengan demikian, ketiga nama di atas dapat dikatakan sebagai identitas jenis kelamin seorang perempuan. Putri Nur Nirmala Sari, memiliki makna sebagai seorang prempuan yang memiliki paras cantik atau bercahaya yang paling sempurna. Hal ini dapat dilihat dari kata Putri yang artinya anak perempuan, Nur yang artinya cahaya dan Nirma Sari yang memiliki arti sebagai sempurna dan paling cantik. Nama tersebut berisi harapan agar sang anak dapat menjadi seorang perempuan yang kecantikkannya paling sempurna, bukan hanya paras wajah tetapi juga akhlak.

Pada nama Annisa Wijayanti, dapat diartikan sebagai perempuan yang kuat. Artinya, ia diharapkan untuk tidak menjadi perempuan yang lemah dan berjiwa layaknya kesatria.

Identitas jenis kelamin terhadap nama diri dapat dilihat melalui beberapa nama seperti Bagus, Joko, Pria, Ayu, Putri, Cantik, Annisa, dll. Kata Bagus, Joko, Pria, melambangkan identitas seorang lakilaki. Kata Bagus dalam Bahasa Jawa diartikan dengan ketampanan, kata Joko dan Pria dalam bahasa jawa dikatakan sebagai laki-laki. Sementara itu kata Ayu dan Cantik, memiliki arti sebagai kata sifat cantik untuk perempuan. Putri diartikan sebagai seorang perempuan. Sedangkan, annisa merupakan bahasa Arab yang memiliki arti perempuan.

\subsection{Bulan Kelahiran}

\begin{tabular}{l|l}
\hline \multicolumn{1}{c|}{ Nama } & \multicolumn{1}{c}{ Bulan Kelahiran } \\
\hline Rahmadani & Ramadan \\
\hline Febrianti & Februari \\
\hline Afril & April \\
\hline Mei & Mei \\
\hline Yuni & Juni \\
\hline Yuli & Juli \\
\hline Agus & Agustus \\
\hline Septi & September \\
\hline Okta & Oktober \\
\hline Novica & November \\
\hline Desi & Desember \\
\hline & \\
\hline
\end{tabular}


1. Winda Ayu Rahmadani

Rahmadani, Ramadhan, merupakan bentuk variasi nama orang yang lahir di bulan Ramadan. Ramadhani digunakan sebagai penanda jenis kelamin perempuan, dan ramadhan digunakan sebagai penanda jenis kelamin laki-laki. Umumnya, nama ini digunakan bagi orang-orang yang beragama Islam atau bagi orang muslim. Penggunaan nama ini umumnya digunakan bagi orang yang lahir pada bulan Ramadan. Bulan Ramadan sendiri merupakan salah satu dari 12 (dua belas) bulan Islam.

Secara keseluruhan, nama Winda Ayu Ramadhani tersebut dapat diartikan sebagai perempuan cantik yang lahir pada bulan Ramadan.

2. Wahyu Afril Lia

Afril, Avri, April merupakan variasi dari penggunaan nama bulan untuk nama orang. Penggunaan nama tersebut didasari karena sang penyandang nama lahir pada bulan April. Pada nama orang di atas variasi bulan April sebagai nama orang dapat dilihat dari kata Afril.

Secara keseluruhan, nama tersebut memiliki makna yaitu perempuan yang membawa berita baik dan petunjuk dari Allah yang lahir di bulan April.

3. Novica Nur Fadillah

Novia, Novica, Novita merupakan Bentuk variasi nama orang yang diambil dari bulan November. Hal ini didasari karena penyandang nama tersebut lahir di bulan November. Dilihat secara keseluruhan, nama tersebut memiliki makna sebagai cahaya utama yang lahir di bulan November. Hal ini dapat dilihat dari kata Nur yang artinya cahaya, Fadilah yang memiliki arti sebagai keutamaan dan Novica merupakan bentuk nama yang diambil dari kata November.

Selain diambil dari urutan kelahiran, pemberian nama di masyarakat Kadus IV, Desa Tegalsari juga menggunakan bulan kelahiran sebagai identitas kapan anak tersebut lahir. Hal ini, dilakukan oleh beberapa orangtua untuk mempermudah mengingat bulan kelahiran anaknya. Pemberian nama ini juga menjadikan pengingat bagi kerabatnya untuk memberikan ucapan selamat ulang tahun kepada penyandang nama. Selain pemberian nama tersebut mengacu pada 12 bulan pada kalender masehi, pemberian nama juga mengacu pada kalender hijrian (Islam)

\subsection{Nama dari Sifat Benda}

\begin{tabular}{l|l}
\hline Nama Orang & Nama Benda \\
\hline Dea Intan Pratiwi & Intan \\
\hline $\begin{array}{l}\text { Anandita Lintang } \\
\text { Persada }\end{array}$ & Lintang \\
\hline $\begin{array}{l}\text { Flowwi Zaaqiyah } \\
\text { Jelitanie }\end{array}$ & $\begin{array}{l}\text { Flowwi (Flower = } \\
\text { Bunga) }\end{array}$ \\
\hline
\end{tabular}




\section{Dea intan Pratiwi}

Nama Dea intan Pratiwi merujuk pada benda intan. Intan merupakan batu permata yang berkilau dan kilaunya mampu memesona setiap orang yang melihatnya. Penamaan nama intan sendiri dapat dikatakan sebagai penanda jenis kelamin perempuan, sebab hal-hal yang berhubungan dengan benda yang berkilau pasti memiliki sifat yang cocok untuk perempuan.

Dengan demikian, penamaan nama intan ini dapat dikatakan agar anak tersebut memiliki paras kecantikan yang berkilau layaknya intan permata. Pemberian nama Dea Intan Pratiwi ini dapat dikatakan sebagai dewi atau perempuan yang paling cantik di muka bumi. Hal ini merujuk pada kata Dea yang berarti Dewi dan kata Pratiwi yang memiliki arti bumi.

2. Anandita Lintang Persada

Kata Lintang pada nama Anandita Lintang Persada dalam bahasa Jawa memiliki arti sebagai bintang yang bersinar. Hal ini menandakan bahwa nama Lintang diambil dari salah satu benda. Dengan demikian, pemberian nama Anandita Lintang Persada memiliki makna sebagai anak perempuan yang bertempat tinggal baik dan bersinar seperti bintang.

Makna secara keseluruhan dari nama tersebut adalah berisi harapan agar anak tersebut memiliki kedudukan yang baik di mana pun dan bersinar layaknya bintang yang terang di malam hari.

3. Flowwi Zaaqiyah Jelitanie

Pemberian nama anak terhadap generasi alfa di atas, ditemukan satusatunya di Kadus IV. Pemberian nama Flowwi Zaaqiyah Jelitanie yang memiliki makna sebagai bunga yang tumbuh cantik sekali ini diambil dari beberapa nama benda, sifat dan terinspirasi dari tokoh dongeng. Kata Flowwi diambil dari kata flower yang dalam Bahasa Indonesia berarti bunga. Kata Zaaqiyah diambil dari bahasa Islami yang diharapkan menjadi bayi perempuan yang mempesona, ramah, bahagia dan ceria. Sedangkan, nama Jelitanie diambil dari salah satu tokoh dongeng. Putri Jelitanie atau Putri Kemarau merupakan salah satu tokoh dongeng yang rela berkorban menceburkan dirinya ke laut demi kesejahteraan rakyat ayahnya yang mengalami kekeringan.

Dengan demikian, pemberian nama Jelitanie ini juga menaruh harapan agar sang anak memiliki rasa rela berkorban dan peduli terhadap sesama.

\section{Beberapa nama benda yang} kemudian dijadikan sebagai nama diri pada masyarakat di Kadus IV, Desa Tegalsari ini banyak digunakan untuk jenis kelamin perempuan. Beberapa orangtua 
ingin mengambil sifat atau karakter asli dari masing-masing benda. Sifat atau karakter tersebut terlihat seperti indah, cantik, harum, bersinar, dsb. Pemilihan nama-nama benda tersebut menggambarkan karakter yang disukai perempuan.

4.6 Nama Mengandung Sifat Manusia

\begin{tabular}{c}
\hline Nama \\
\hline Ayra Shirly Alnaira \\
\hline Budhi Nirmalajati \\
\hline Aditya Rifqi
\end{tabular}

1. Ayra Shirly Alnaira

Penamaan nama diri Ayra Shirly Alnaira mungkin menjadi satu-satunya nama yang ditemukan di Dukuh BanaranBugel Kadus IV ini. Nama tersebut memiliki makna sebagai anak perempuan yang diberkati Allah dan berhati bersih seperti padang rumput yang terang dan gemerlap. Maksud dari pemberian nama tersebut berisi harapan dari orang tua agar anaknya selalu mendapat berkat dari Allah dan memiliki kesucian dan ketulusan hati yang diibaratkan seperti padang rumput yang terang sekaligus memiliki sikap gemerlap atau berkilau yang dapat diartikan sebagai perempuan yang cantik, baik cantik di hati maupun penampilannya.

2. Budhi Nirmalajati

Nama Budhi tentu sudah tak asing lagi di telinga masyarakat. Nama Budi pertama kali dikumandangkan dalam organisasi yang bernama Boedi Oetomo. Dari sinilah inspirasi nama Budi diambil yang memiliki makna sebagai orang yang berakhlak.

Kata Nirmalajati dalam pemberian nama tersebut merujuk pada makna kata suci dan murni. Hal ini memiliki makna sebagai anak perempuan berakhlak yang suci dan murni. Maksudnya, nama tersebut berisi harapan agar ia memiliki akhlak mahmudah yang benar-benar suci dan murni, baik dari tutur kata maupun perbuatan.

\section{Aditya Rifqi}

Nama Aditya di Dukuh BanaranBugel tidak sedikit ditemukan. Dari beberapa nama-nama Aditya yang ada, nama Aditya Rifqi diambil karena memiliki proses penamaan yang simpel dan memiliki makna yang mendalam. Aditya dalam bahasa India atau bahasa Sansekerta dimaknai sebagai orang yang pandai dan bijaksana.

Sedangkan kata Rifqi memiliki makna sebagai orang yang lemah lembut. Penamaan nama diri Aditya Rifqi ini memiliki makna harapan agar sang anak nantinya memiliki sifat atau karakter yang bijaksana dan juga lemah lembut. Maksud dari lemah lembut sendiri adalah orang yang memiliki karakter yang berbudi pekerti luhur dan arif. 
Pemberian nama di era generasi milenial maupun generasi alfa tidak luput dari nama-nama yang mengandung sifat atau karakter. Hal ini dimaksudkan bahwa nama adalah doa. Sehingga, orang tua berharap bahwa anaknya dapat memiliki karakter atau sifat sesuai dengan arti dari nama yang dimilikinya. Beberapa nama yang mengandung sifat atau karakter masyarakat di Kadus IV, Desa Tegalsari ini banyak diambil dari nama-nama popular.

Nama-nama tersebut mengandung arti kata sifat seperti, bijaksana, pandai atau cerdik, berahklak, suci atau bersih, dsb.

\subsection{Nama Mengandung Harapan}

\begin{tabular}{l}
\hline \multicolumn{1}{c}{ Nama } \\
\hline Arzan Dzakiandra Alhusayn \\
\hline Kunti Nihayatul Mahmudah \\
\hline Ferdian Achsani \\
\hline
\end{tabular}

1. Arzan Dzakiandra Alhusayn

Kata Arzan diambil dari bahasa Arab yang memiliki arti orang yang berguna. Dalam hal ini, pemilik nama Arzan mengandung harapan agar ia menjadi laki laki yang suka menolong, baik dan rendah hati. Kata Dzakiandra dalam bahasa Arab dapat dijadikan sebagai penanda jenis kelamin karena memiliki arti cerdas dan jantan, sehingga dapat dikatakan sebagai penanda bahwa pemilik nama tersebut adalah berjenis kelamin laki-laki.

Begitu juga dengan kata Alhusayn juga dapat dikatakan sebagai penanda jenis kelamin sebagai anak laki-laki, karena memiliki makna tampan dan baik. Jika digabungkan, secara keseluruhan nama tersebut memiliki harapan sebagai pria tampan yang baik, cerdas, jantan, murni dan terhindar dari dosa dan menjadi orang yang berguna.

2. Kunti Nihayatul Mahmudah

Nama lengkap Kunti Nihayatul Mahmudah merupakan salah satu nama yang secara keseluruhan diambil dari bahasa Arab. Hal ini dilatarbelakangi oleh faktor sosiologi dari ayahnya yang merupakan pemuka agama ataupun lulusan dari pondok pesantren. Nama Kunti di sini bukan diambil dari nama ibu Pandawa Lima seperti pandangan beberapa orang pada umumnya, tetapi merupakan gabungan dari fi'il madli كان, mudlori' amr aki Maka, Kun fi'il amr yang artinya 'jadilah'. Kemudian, Tii diambil dari kalimat anta atau anti yang merupakan sebutan pengganti bagi sebutan laki-laki (anta) dan perempuan (anti).

Selanjutnya. kedua kata tersebut digabung menjadi kunti, yang memiliki Arti Jadilah anak perempuan. Kata Nihayatul juga diambil dari bahasa Arab yang memiliki arti terakhir, sedangkan 
Kata Mahmudah dalam bahasa Arab memiliki arti terpuji. Dengan demikian, dapat disimpulkan bahwa arti dari nama Kunti Nihayatul Mahmudah berisi harapan yaitu jadilah anak perempuan yang akhir kehidupannya terpuji.

3. Ferdian Achsani

Nama Ferdian Achsani merupakan satu-satunya nama yang ditemukan di dukuh ini. Nama tersebut merupakan gabungan dari bahasa Irlandia dan bahasa Arab. Kata Ferdian diambil dari bahasa Irlandia, memiliki makna sebagai seorang pemimpin. Selanjutnya, kata Achsani merupakan nama yang diambil dari potongan surat At-Tin ayat 4 بأَحْسَنَ yang memiliki makna sebaik-baiknya. Dengan demikian, nama tersebut memiliki makna harapan agar ia menjadi pemimpin yang baik (adil).

Beberapa nama masyarakat di Kadus IV, Desa Tegalsari yang mengandung harapan banyak ditemukan diambil dari bahasa Arab. Hal ini didasari dari faktor keagamaan di Kadus IV yang sebagian besar adalah beragama Islam. Orang tua ingin memberikan nama kepada anaknya dengan bernuansa islami dan mengandung harapan sesuai dengan keinginannya. Beberapa nama-nama tersebut memiliki harapan agar menjadi orang yang baik, terpuji, adil, dll.
4.8 Gabungan Nama Orang Tua

\begin{tabular}{ll|l}
\hline Nama Anak & Nama Orang Tua \\
\hline $\begin{array}{l}\text { Shakuntala Zahra } \\
\text { Santoso }\end{array}$ & Joko Santoso \\
\hline $\begin{array}{l}\text { Maryan Aida } \\
\text { Istiqomah }\end{array}$ & $\begin{array}{l}\text { Mardiyo (Mar) } \\
\text { Dan Sardiyanti } \\
\text { (Yan) }\end{array}$ \\
\hline Lusi Tri Winarni & Winarni \\
\hline
\end{tabular}

1. Shakuntala Zahra Santoso

Nama Shakuntala Zahra Santoso merupakan satu-satunya nama yang ditemukan di Dukuh Banaran-Bugel. Nama Santoso yang berada di belakang kata ini merupakan kata yang diambil dari nama ayahnya yang bernama Joko Santoso.

Nama Santoso ini dalam Bahasa Jawa memiliki arti kuat. Nama Shakuntala diambil dari bahasa Sansekerta yang artinya burung dan nama Zahra diambil dari Bahasa Arab yang memiliki arti cantik. Secara keseluruhan, nama ini memiliki makna sebagai burung cantik dan kuat.

2. Lusi Tri Winarni

Nama Lusi tri Winarsih diambil dari nama ibunya yang bernama Winarsih. Dengan demikian, dapat dijadikan identitas penanda bahwa ia adalah anak dari Winarsih. Tetapi, bukan hanya identitas penanda bahwa ia adalah anak dari ibu yang bernama Winarsih, tetapi di dalam nama tersebut juga sebagai penanda bahwa ia adalah anak ketiga. 
Hal ini dapat dilihat dari kata tri yang terletak di tengah-tengah nama tersebut. Hal ini sebagai penegasan bahwa nama tersebut mengandung arti sebagai cahaya ketiga Winarsih. Maksudnya adalah anak yang bernama Lusi Tersebut merupakan buah hati ketiga Winarsih.

3. Maryan Aida Istiqomah

Nama Maryan Aida Istiqomah merupakan satu-satunya nama yang ditemukan di Dukuh Banaran-Bugel. Nama Maryan ini diambil dari gabungan nama ayah dan ibunya yang bernama Mardiyo (Mar) dan Sardiyanti (Yan). Kata Aida berarti suka menolong dan kata Istiqomah memiliki arti orang yang tulus. Secara keseluruhan, nama tersebut mengandung harapan sebagai gadis pilihan dari Mardiyo dan Sardiyanti yang memiliki ketulusan untuk menjadi seorang penolong.

Pemberian nama orangtua yang disisipkan pada nama anak umumnya bukan suatu hal yang baru. Tetapi, bagi masyarakat di Kadus IV, Desa Tegalsari, hal ini menjadi sesuatu yang jarang ditemui. Artinya, hanya beberapa orangtua yang memberikan namanya pada anaknya. Pemberian nama ini digunakan sebagai penanda atau identitas keluarga bagi si anak. pemberian nama orang tua pada nama anak di Kadus IV ini dapat dilihat seperti menggabungkan kedua nama orang tua, memberikan nama panggilan ibu atau ayah, memberikan nama suku kata terakhir sang ayah, dsb.

\section{Penutup}

Nama diri merupakan identitas jati diri seseorang sebagai pembeda antara satu orang dengan yang lainnya. Pemberian nama masyarakat di Kadus IV Desa Tegalsari yang dahulu menggunakan nama-nama tradisional yang diambil dari pasaran atau weton, kini mengalami perubahan. Prsoses pemberian nama melalui weton atau pasaran tersebut mulai ditinggalkan oleh masyarakat. Masyarakat dukuh Banaran-Bugel kini beralih ke penggunaan nama-nama modern dan mulai meninggalkan pemberian nama secara tradisional tersebut.

Hasil penelitian ini menegaskan bahwa penamaan nama-nama masyarakat Dukuh Banaran-Bugel Desa Tegalsari pada generasi milenial hingga generasi alfa menunjukkan adanya perkembangan nama-nama yang lebih modern. Hal ini dapat dilihat dari adanya perubahan namanama yang ditandai dengan adanya unsur bahasa asing seperti bahasa Arab, India, atau sansekerta; dan penggunaan bahasa Jawa. Selain itu, faktor psikologi dan sosiologi memengaruhi proses pemberian nama. Proses penamaan masyarakat ini dapat dilihat dari beberapa hal, seperti 
urutan lahir, terinspirasi tokoh, penanda jenis kelamin, bulan kelahiran, sifat benda, nama mengandung sifat, nama mengandung harapan, dan gabungan nama orang tua.

\section{Daftar Pustaka}

Aditya, F., Saman, S. \& Syam, C. (2016). Penamaan Orang Melayu di Kampung Tanjung Mempawah. Jurnal Pendidikan dan Pembelajaran Khatulistiwa, Vol 6,(No 12), 1--10.

Ascalonicawati, A. P. (2019). Variasi Pemilihan Nama Pada Generasi Alfa. In Peran Muhamaddiyah dalam Riset Sains dan Teknologi di Era Revolusi Industri 4.0 Menuju Ketercapaian $S D G$ 's (pp. 292--297).

Bandana, I. G. W. S. (2015). Sistem Nama Orang Bali: Kajian Struktur dan Makna. Aksara, 27(1), 1--11.

Corbuzier, D. (2019). Viral Kakak Beradik Bernama: Republik, Indonesia, dan Merdeka | Hitam Putih (21/08/19) Part 2. Retrieved from https://www.youtube.com/watch?v=o e1zb4-4jZk\&t=389s

Dewi, R., Roni, L., \& Paulina, P. (2012). Motivasi Penamaan Manusia Toraja. Jurnal KIP, VII (3), 31--35.

Fatikhudin, P. (2018). Penamaan Tempat Usaha Berbahasa Asing di Surabaya: Kajian Semantik Kognitif. BASINDO : Jurnal Kajian Bahasa, Sastra Indonesia, dan Pembelajarannya Volume, 2 (2), 88-99.

Khotimah, K., \& Ika, F. (2019). Kajian Semantik Nama Diri Mahasiswa
Madura di Prodi Pendidikan Bahasa dan Sastra Indonesia Universitas Trunojoyo Madura. Jurnal Pendidikan Bahasa Dan Sastra Indonesia, 8(1), 51--55.
Resticka, G. A., \& Sri, N. H. Y. (2018). Bentuk Satuan Kebahasaan dalam Nama Diri Orang Masyarakat Banyumas. In Pengembangan Sumber Daya Perdesaan dan Kearifan Lokal Berkelanjutan (pp. 179--190).

Rohardiyanto, I. (2019). Komprehensi Psikososiosemantik Nama Diri Mahasiswa IAIN Surakrta, II (2), 169--196.

Sugiyono. (2012). Metode Penelitian Kuantitatif, Kualitatif, dan $R \& D$. Bandung: Alfabeta.

Temaja, I. G. B. W. B. (2017). Sistem Penamaan Orang Bali. Humanika, 24(2), 60--72. 